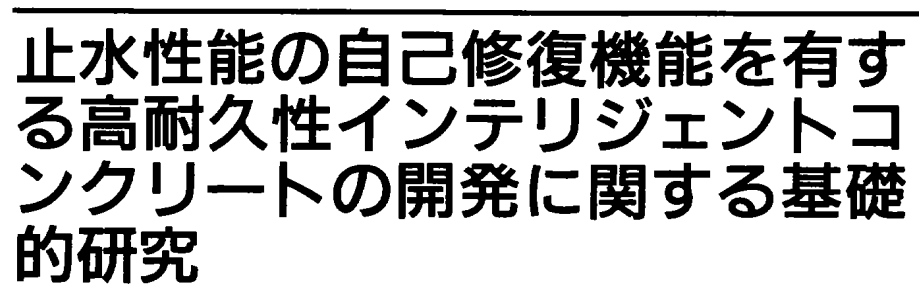

\section{FUNDAMENTAL STUDY ON DEVELOPMENT OF INTELLIGENT CONCRETE WITH SELF-HEALING CAPABILITY FOR PREVENTION OF WATER LEAKAGE}

三橋博三 — $* 1 \quad$ 金子佳生 - - 2

キーワード :

インテリジェントコンクリート，自己传復機能，止水性能，高耐久性，神传硢

Keywords :

Intelligent concrete, Self-healing capability, Prevention of water leakage, High durability, Repair agent
HirOzO MIHASHI — $* 1$ Yoshio KANEKO $-* 2$

In this paper, a fundamental study is carried out to develop intelligent concrete with self-healing capability for prevention of water leakage. Conceptual methodology consisting of three functions of sensing, processing and executing is proposed. In the method, crack repairing agents are installed as core materials in shell bodies embedded in concrete structures. The feasibility of the proposed approach is clarified experimentally by making use of glass pipes as shell bodies containing crack repairing agents.

\section{1. はじめに}

近年、コンクリート榑造物の早期劣化の可能性が曊在化して以 降、その高耐久性化への社会的要請が大きくなってきている。しか し、コンクリートの性質上、種々の要因により発生するひび割れに よる劣化の促進は避けられないものとして受けとめられてきた。こ れらの劣化を修復することはおろか検査することもできない場合も 考えられ、大きな社会問題となる可能性を含んでいる"。

一方、環境条件の変化に応じて材料自体に自己制御機能や自己修 復機能を持たせたインテリジェント材料の開発が最近各分野で取り 上げられている。これは、情報の概念を取り入れ、ある状態量をセ ンサ機能によって検知し、その情報をプロセッサ機能によって処理 してあるレベルで判断し、それに基づきアクチュエータ機能によっ て能動的に行動を実行できるような機能を材料自身に組み込んだも のである。このインテリジェント材料の概念を導入した高機能性コ ンクリートに関する研究は、これまてにも幾つか報告されており、

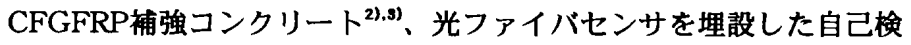
知コンクリート"、強度の自己修復コンクリート ${ }^{55,8)}$.7)、さらに自己 腐食防止機能 ${ }^{81,98}$ や自己強物化機能 ${ }^{(0)}$ をコンクリートに付与させた高 耐久性コンクリートなどがある。

これらは1つの機能に特化し、そのインテリジェント化を図った ものであり、対象とする機能は様々存在する。言い換えると、全て の機能を一括に実現するのは困暮であることを示している。本研究 では、これまで強度の自己修復機能に関するインテリジェント化の 基砹研究を行ってきた"”。本論では、これまでの研究を発展させ、 セメント系材料と反応し、カラス析出物を生成させて空隐を充
填することにより、止水機能を向上させることが既に確認されてい る補修剤を用いて、ひび割れ部分からの䨕水を自動的に防ぐ機能を 付与させたコンクリート、即ち高耐久性インテリジェントコンクリ 一トの可能性について検討した基礎的研究の結果を報告する。

\section{2. インテリジェント化の手法}

本研究で提案するインテリジェント化手法を、平成元年に出され た科学技術庁航空・雨子等技術審議会第 13 号答申で表された棈造材 料のインテリジェント化の姿 ${ }^{(2)}$ に基づいて、図1に示す。

因は、「殻」により保護されている「コア」としての補修郕が、 母材であるコンクリートの破懐に反応した「投」の破滾によってそ の破壤箇所に放出されて補修を行うシステムを示している。即ち、 ひび割れがコンクリート中に発生すると、その中に配置された 「教」も破滾（破烄の発生を検知）し、内包していた「コア」であ る補修剤を放出（補修を行う必要性を判断）、破壞筒所にその補修 用を浸透させてひび割れを塞ぐ（補修を実行する）ものである。こ の機構が墈くことで、材料自体の判断の下に、能動的に自己修復を 行うことが可能になるものと考えられる。

ここではガラス管と補修㓮を用いてコンクリートのインテリジェ ント化を図る。即ち、コンクリートにひび割れが生じるとカララス管 が破断し（センサ機能）、カラス管に内包されている補修郕が破断 部から流出し（プロセッサ機能）、ひび割れに補修郕を浸透させて 塞ぐ（アクチュエータ機能）というプロセスである。カラス管を使 用することの利点は、ひび割れという損賃に対し敏感に反応するこ と、補修剤を末反応のまま比較的多量に保存できることにある。

\footnotetext{
*1 東北大学大学院工学研究科 教授 - 工博

（干980-8579 仙台市青葉区荒巻字青葉06)

*2 東北大学大学院工学研究科 助教授 P Ph.D.
}

\footnotetext{
*1 Prof., Tohoku University, Graduate School of Engineering, Dr. Eng.

*2 Assoc. Prof., Tohoku University, Graduate School of Engineering, Ph.D.
} 
(1) ひび割れがガラス篮にまでお よひ、ガラス管が端断する

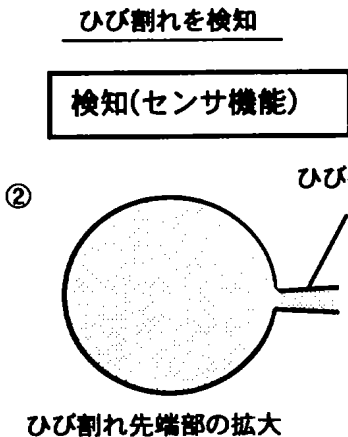

ひひ割れ先站部の抾大

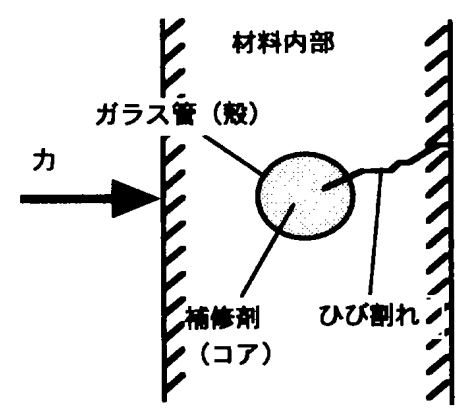

㭪化詴がモの政断部から流出

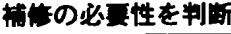

(3)

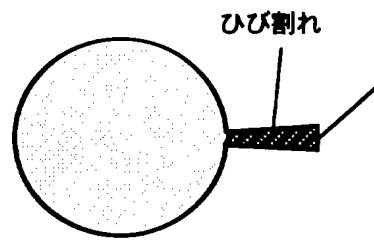

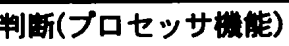

カラス家析出物

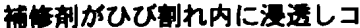
ンクリートと反応、カラスス面析 出物を生成し、ひび割れを害く

\section{械像を实行}

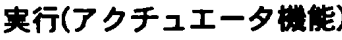

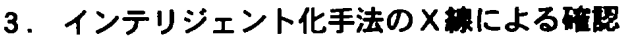

図 1 で示したインテリジェント化手法の可能性を確認するため

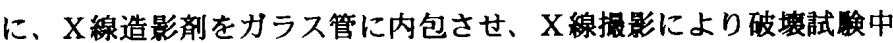
の試験体内部の様子を覞察する。

\section{1 試会体及び实験方法}

図 2 に示す樑さ $2.5 \mathrm{~cm}$ のノッチを付けた試䥐体を用いて、3 点曲 げ試娩を行う。使用材料は、早強ポルトランドセメント(比重 $\rho$ =3.13)、混和材にシリカフューム $(\rho=2.20)$ 、混和剤にナフタリンス ルホン酸塩系高性能減水剈(空気非連行性 $/ \rho=1.20$ )、細骨材に宮城 県阿武限川産川砂 $(\rho=2.54$; 表乾)、補強瀻維にポリプロピレン䄉 維 $(\rho=0.91 /$ 直径 $0.018 \mathrm{~mm} \phi \times$ 長さ $12 \mathrm{~mm})$ を用いた。調合は $\mathrm{W} / \mathrm{B}=40(38$ (水) +2 (高性能娍水剂) $) \% 、 \mathrm{SF} / \mathrm{B}=10 \% 、 \mathrm{Va}$ (骨材体 積) $: \mathrm{Vm}$ (マトリクス体積) $=1: 1 、 \mathrm{Vf}=0.5 \%$ とする。但し、Wは水、 $\mathrm{B}$ は結合材、SFはシリカフューム、Vfは織維混入率(体積表示)を示 す。その他、カララス管(外径 $2 \mathrm{~mm}$ 、内径 $0.8 \mathrm{~mm}$ )及びX線造影剤(主 成分は炭酸セシウム)を用い、カラス管を試挽体内部に埋設してお り、図2に示すように外部からX線造影夙を供給する。

練り混ぜには強制練りミキサを使用し、空練りを 1 分間、水及び 減水剤を加えて 3 分間、織維を加えて 1 分間、骨材を加えて 2 分間 とした。打設から 24 時間後に脱型し、養生室 $\left(20^{\circ} \mathrm{C} /\right.$ 相対湿度 $\left.100 \%\right)$ にて材令 7 日まで湿空養生を行った。その後、コンクリートカッタ 一で試絤体中央に深さ $2.5 \mathrm{~mm}$ のノッチを設けた。載荷は、ひび割れ 開口変位（CMOD : Crack Mouse Opening Displacement）により制 御し、渐増载荷と共に連綍的にX線透過撮影を行い、载荷中はリア ルタイムで画像処理した映像をTVモニタで観察した。

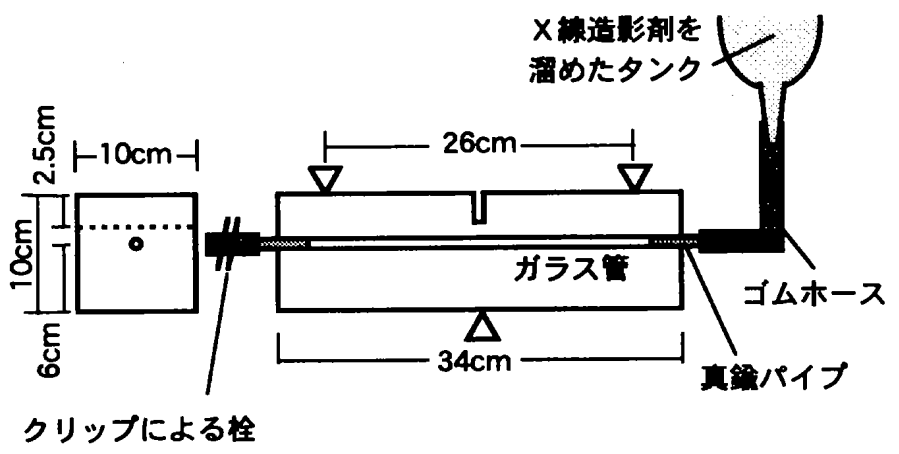

图 2 武亦体の形状

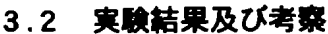

曲げ試䀦結果及びX線により覾察されたノッチ先端（写真上部の 白色部）近傍の試験体内部の写真を図 3 に示す。荷重一CMOD曲線 におけるプロット数字は写真中の数字に対応している。写真より、 母材の破壊に反応してカラス管も破滾し、内包するX線造影剤のひ び割れ中への放出が確認できる。この結果、X線造影肪と補修剤を 入れ換えれば、カラス管の埋設により同様な挙動が再現できると判 断する。
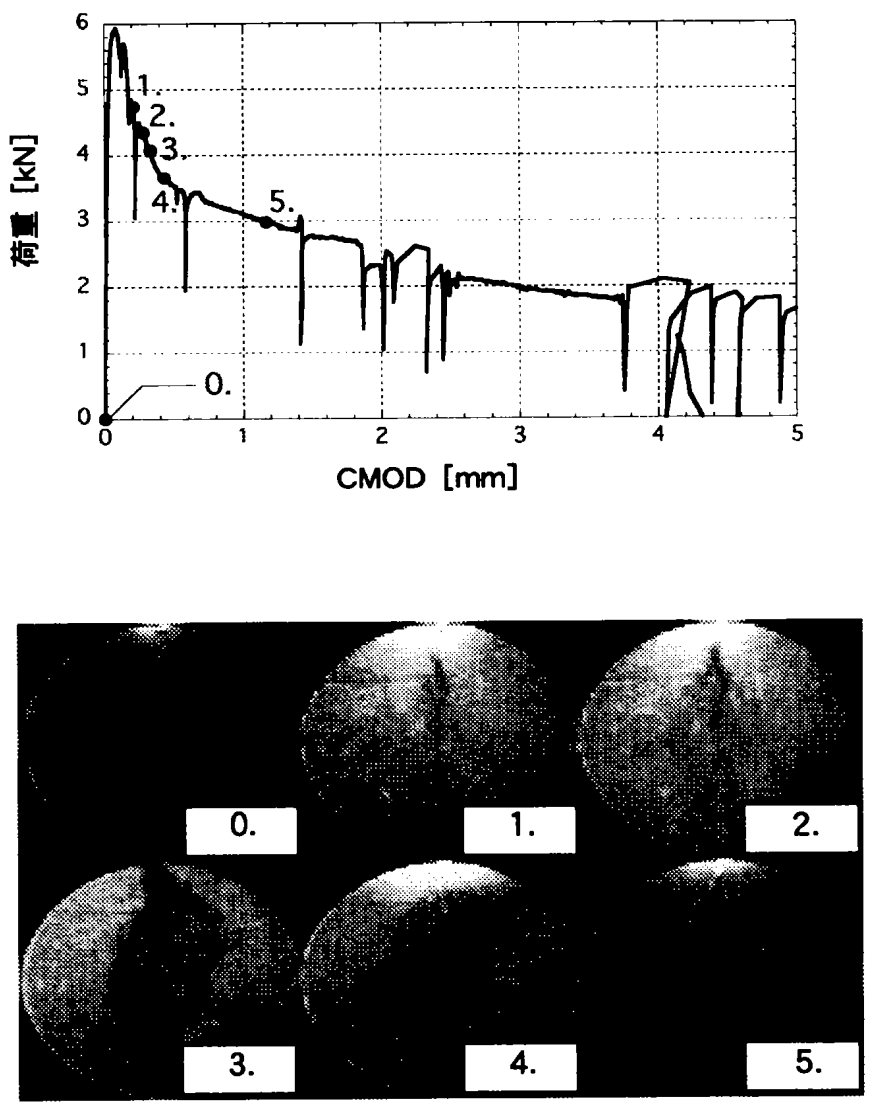

图 3 荷 


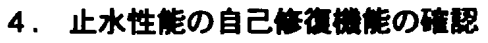

\section{1 榑供都}

ここで用いる補修剤は珪酸アルカリを主成分とする水溶液で、コ ンクリートやモルタルへの浸透性㷛機筫反店型改筫郕である。有機 高分子系の防水用や改筫用とは異なり、コンクリートやモルタルな どの多れ筫材料に塗布し、浸透させることにより、アンモニウムイ オンとハロゲンイオン存在下で珪酸カルシウムとコロイド珪酸を生 成させ、材料のれを完全に充填し無孔化する。即ち、コンクリート 内部のカルシウムイオン、マグネシウムイオン、アルミニウムイオ ンと置換反応を起こし、コンクリートの浸透部及び表面に不溶性の 結晶体（ガラス物筫）を形成する。

\section{2 式雊及ひ実信方法}

図 4 に示す上下に $5 \mathrm{~mm}$ のノッチを付けた試跧体を用いて、割裂破

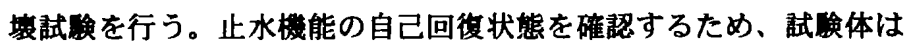
補修刜を用いないもの(c05)、従来の補修郕使用方法として割裂試酸 により発生したひび割れに対して表面から手作業で㙰布することに より補修を行うもの(c05-B)、カラス管を埋設して外部から補修剂 を供給することによりインテリジェント化を図るもの(c05-g)を用 いる。

使用材料、及び調合は3.1節で示した試跧体と同様である。但し、 試跧体の補强のために異形铁筋(D10)を埋設するとともに、X線造 影剤にかわってカラス管内には禣修郕を内包させる（図4）。

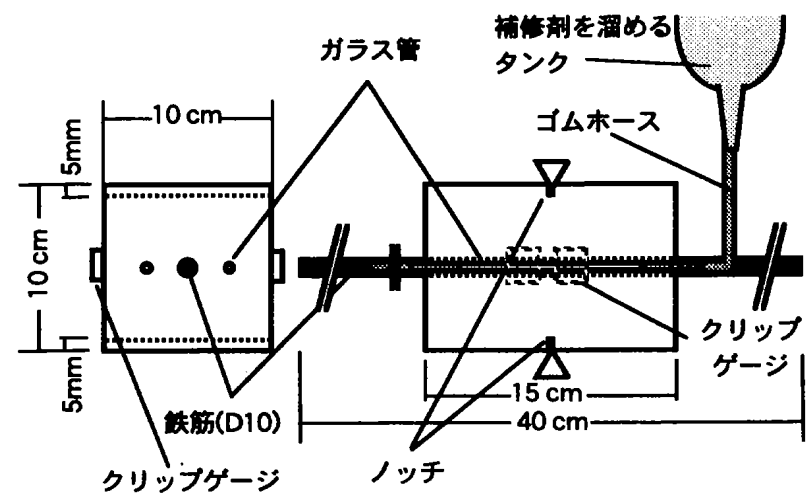

図4 試保体の形状(c05,c05-Bはガラス简が埋設されない)
練り混ぜはオムニミキサを用いて3.1節の試跧と同様に行った。打 設から24時間後に脱型し、蒸気蓄生(昇温速度 $10^{\circ} \mathrm{C} / \mathrm{h} 、 80^{\circ} \mathrm{C}$ に 5 時間保持の後自然冷却)を行う。この後に恒温室 $\left(20^{\circ} \mathrm{C} /\right.$ 相対湿度 50\%)にて材令 3 日まで静圈し、破滾試跧及び止水処理を行った。

割裂破烄試䀫は、クリップゲージで测定したCMODが十分に開い た時点で除荷し、载荷を終了する。その後恒温室で 3 日間、補修肪 を供給しながら養生を行った。その間、㭪修剤の非対称な浸透を防 ぐため図 5 のように静圈した。

透水試跧は、図 6 に示すように試険体のノッチ面と直行する面に 漏斗を取り付けて行い、一定量の水分が失われる時間を測定した。

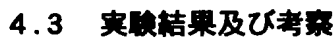

図 7 に全シリーズの透水時關と透水量の関係を示す。図中、定性 的㑯向を明確にするため、各シリーズ毎に彩色した分布領域を示し ている。四は、透水速度（透水量の增分／透水時間增分）が時間と ともに多孔䁈媒体内の毛細管力の娍少によりしだいに娍少し、定常 流れにおける流速に近付いていることを示している。また、c05シ リーズとc05-Bシリーズとでは大きな差がないのに対し、c05-gシ リーズは他のシリーズと比ベ大きく右側にグラフが開し、同一時 間の透水量がより少ないことを示している。即ち、カラス管を埋設 することにより、手作業による表面からの補修に比較して補修効果 がはるかに高いことが明らかになったといえる。

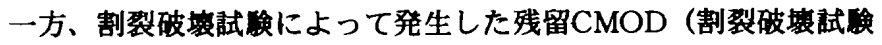
除荷後試略体に残ったCMOD）による透水時間の差を確認するた め、各シリーズ毎の残留CMODと $5 \mathrm{cc}$ 透水に要した時間との関倸を 図8に示す。図中、定性的傾向を明確にするため、各シリーズ毎に 線形回师線を示している。眓より、残留CMODの全ての筑囲にわ たって、c05-gシリーズが図の上方に分布し透水時間が長いことが わかる。さらに、他のシリーズと比べ残留CMODが小さい程透水時 間の増加㑯向が大きいことより、残留CMODを確実に制御すれば、 止水性能の向上がより影著となることも既察できる。なお、c05-B シリーズは、残留CMODが大きい程透水時間が増加する㑯向を示し ているが、これは表面に洛布された止水肪が内部に浸透するために はある程度のひび割れ幅が必要であること、及び手作業によるばら つきに起因するものと考えられる。

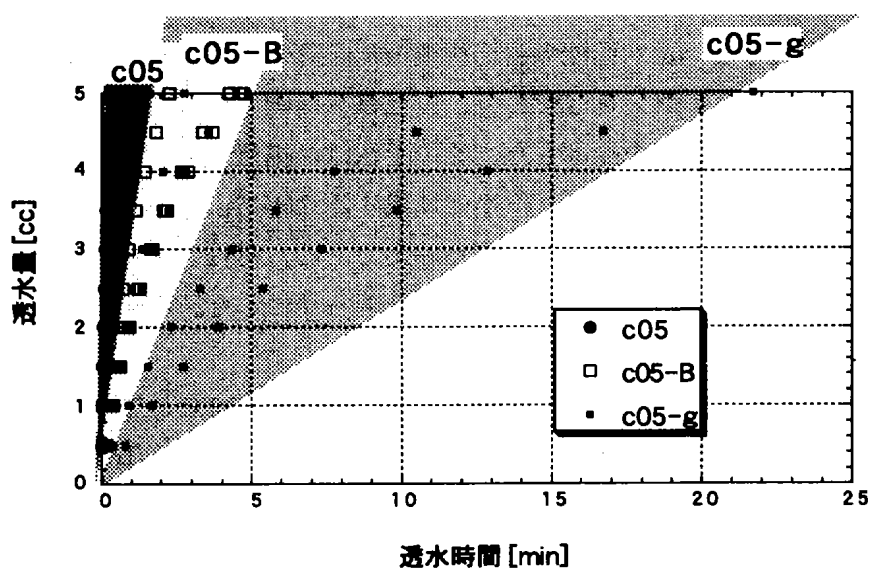

图 7 各シリースの这水時问と运水量の时係
图 5 c05-gの解方法

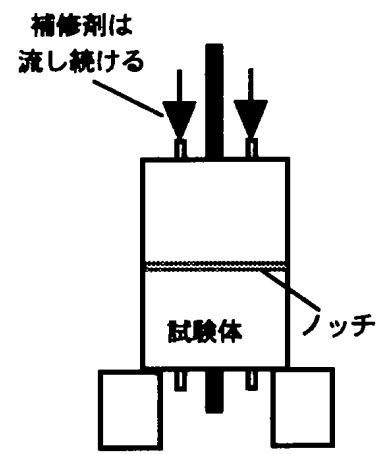

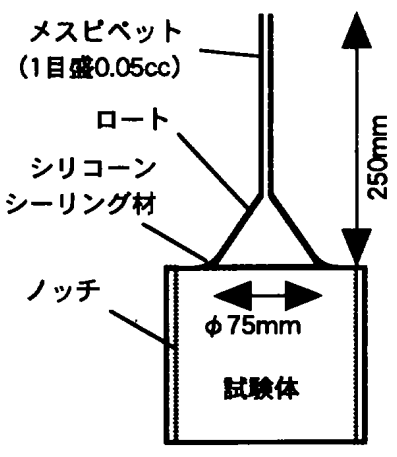

图 6 透水試确方法 


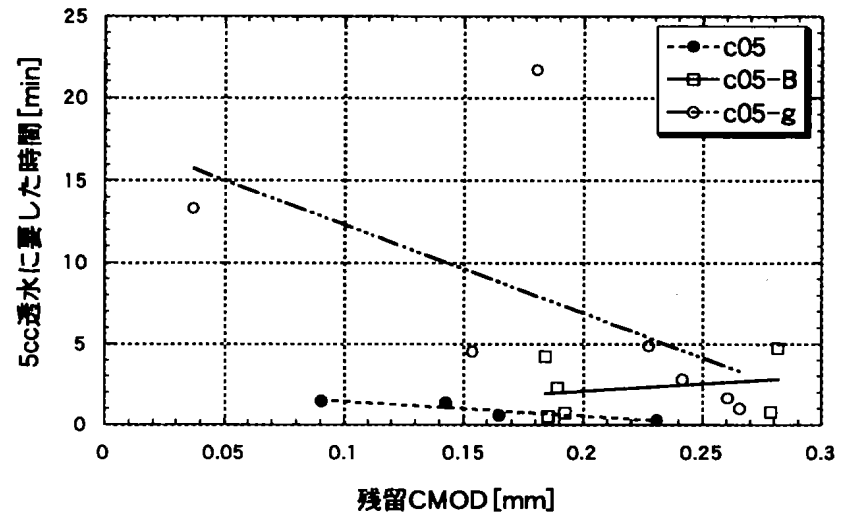

図8 残留CMODと莩水時间の閶保

次に、インテリジェント化手法として用いたカラス管により、構 造物の耐力が低下するかどうかを確認するため、カラス管を用いた 場合 (c05-gシリーズ) とカラス管を用いない場合（c05シリーズと c05-Bシリーズ）の割裂破滾試験時の最大荷重の比較を図 9 に示 す。図は最大値と最小値、及び平均値を示している。また、比較を 明確にするため平均值を直線で結んでいる。図より、カラス管の埋 設により問題となるような顥著な䨛力低下は認められない。

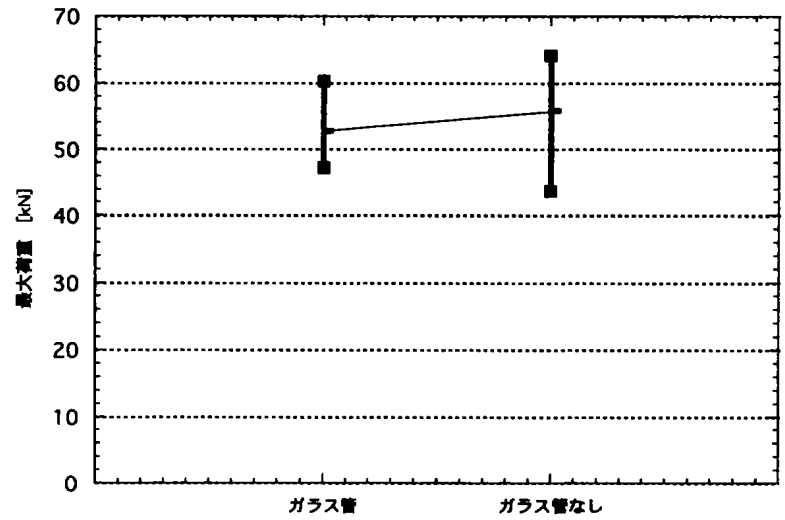

图 9 カララス笛を埋設した场合と埋設しない埧合 との最大強度の比较

\section{5. まとめ}

本研究では、止水性能の自己修復機能を有するインテリジェント コンクリートの開発を目指して、自己修復機能というインテリジェ ント化を行う手法を提案した。その手法は、補修郕をカララス管に内 包して保護し、コンクリート中に埋設することによって、検知・判 断・実行の 3 つの機能を付与するものである。更に、基礎的実跧に より、その機能の付加が可能なことを明らかにした。以下にその要 約を示す。

(1)本研究で用いたインテリジェント化の手法により、コンクリー トのひび割れに対し、センサ及びプロセッサとしてのカラス管 と、アクチュエータとしての補修剤供給システムが有効に的

き、止水性能の自己回復が可能となる。

(2)自己修復による止水性能の回復は、手作業による表面補修の場
合よりはるかに大きく、また止水性能の自己修復機能の発現

は、ひび割れ開口変位を小さくする程暊著となる。

(3)本研究に用いる程度のカラス管埋設により問題となるような顕

著な耐力低下は認められない。

本研究は緒についたばかりであり、現段階では現象論にとどまっ ている。そのため本研究で示した実䀦的検証に加え、補修剤や透水 試埃時の水の挙動を理論的に定量化することにより、確実なインテ リジェント機能の制御を可能にすることが今後の課題と考える。ま た、本研究ではガラス管を殸として各種実跧を行ってきたが、実用 化のための施工性を視野に入れたカプセル化などの材料選択も必要 である。さらに、耐久性を視野に入れた経時変化に対しても、定量 化していく必要があると考える。

\section{解辞}

本研究は、東北大学大学院工学研究科西脇智哉氏（現（株）大林 組）、及び同乾弘泰氏（現日本銅管（株））の大学院前期課程の研 究として実施したものである。ここに記し、謝意を表する。また、 本研究の遂行にあたり、X線を用いた実験にご助力を頂いた東北学 院大学工学部大塚浩司教授、並びに止水剤の御提供を頂いた（株） スリーボンドユニコムの関係者各位に、深謝する。なお、本研究は 平成7年度 平成9年度の科学研究费補助金（基盉研究(A)(1)）（代 表者 : 三檑博三、研究課題番号07555466）による「自己修復機能 を有するインテリジェントコンクリートの開発に関する研究」の一 部である。ここに記し、謝意を表する。

\section{奉考文献}

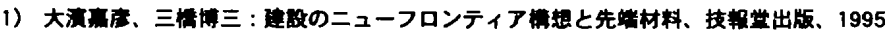

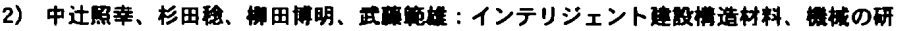
究、vol.44、pp.408-411、1993

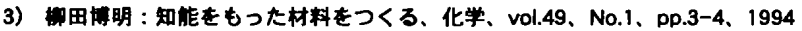

4) Dry,C.M. : Smart Multiphase Composite Materials which Repair Themselves by a Release of Liquid which become Solids. Proceedings of the Society of Photo-optical instrumentation Engineers (SPIE), vol.2444, pp.410-413, 1995

5) Dry,C.M. : Time Release of Chemicals into Hardened Cementitious Matrices for Crack Repair, Fiber Rebond, and Increase in Flexural Toughening. Fractural Mechanics 25th Volume. pp.268-282, 1995

6) Dry,C.M. : Smart bridge and building materials in which cyclic motion is controlled by internally released adhesive, SPIE, vol.2719,pp.247-254、1996

7) Dry,C.M. : Building Materials That Self Repair. Architectural Science Review, vol.40, pp49-52, 1997

8) Dry,C.M. : Smart Materials which Sense, Activate and Repair Damage : Hollow Porous Fibers in Composites Release Chemicals from Fibers for SelfHealing,Damage Prevention, and/or Dynamic Controll, SPIE, vol.1777, pp.367371. 1992a

9) Dry,C.M. : Smart Building Materials which Prevent Damage or Repair Themselves. Materials Research Society Symposium Proceeding, vol.276、pp.311-314、1992

10) Dry,C.M. : Matrix Cracking Repair and Filling Using Active and Passive Modes for Smart Timed Rerease of Chemicals from Fibers into Matrices. Journal of Smart Materials and Structures, vol.3、No.2、pp.118-123、1994

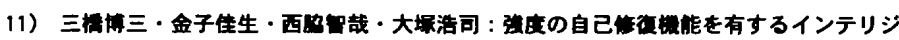

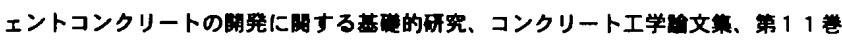

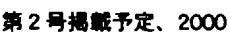

12）松周三都：金風材料のインテリジェント化、セラミックス、vol.28、No.6、pp.581584. 1993

[1999年 8 月13日原稿受理 2000年 2 月 2 日採用決定］ 